Article

\title{
Two New Flavonol Glycosides from Polygala sibirica L. var megalopha Fr.
}

\author{
Yan-Jie Huang ${ }^{1}$, Ling-Yun Zhou ${ }^{1,2}{ }^{\text {, Jun-Min Wang }}{ }^{1}$, Qiang Li ${ }^{1}$, Yuan-Yuan Geng ${ }^{1}$, \\ Hai-Yang Liu ${ }^{3, *}$ and Yan Hua ${ }^{1, *}$ \\ Received: 21 October 2015 ; Accepted: 16 November 2015 ; Published: 2 December 2015 \\ Academic Editor: Derek J. McPhee \\ 1 College of Forestry, Southwest Forestry University, Kunming 650224, Yunnan, China; \\ hyj0106@foxmail.com (Y.-J.H.); zly324@foxmail.com (L.-Y.Z); dawn723@163.com (J.-M.W.); \\ kib312270163@foxmail.com (Q.L.); 18208826431@163.com (Y.-Y.G.) \\ 2 School of Pharmacy, Wannan Medical College, Wuhu 241002, Anhui, China \\ 3 State Key Laboratory of Phytochemistry and Plant Resources in West China, Kunming Institute of Botany, \\ Chinese Academy of Sciences, Kunming 650204, Yunnan, China \\ * Correspondence: haiyangliu@mail.kib.ac.cn (H.-Y.L.); huayan1216@163.com (Y.H.); \\ Tel.: +86-871-6522-3246 (H.-Y.L.); +86-871-6386-3145 (Y.H.)
}

\begin{abstract}
Two new flavonol glycosides, named polygalin $\mathrm{H}$ (1) and polygalin I (2), as well as the known compound polygalin D (3), were isolated from the whole plant of Polygala sibirica L. var megalopha Fr. Their structures were elucidated on the basis of spectroscopic data analysis. These flavonol glycosides exhibited strong inhibitory activities against xanthine oxidase in vitro. Their half-maximal inhibitory concentrations $\left(\mathrm{IC}_{50}\right)$ were calculated, which were 9.48, 8.31, $16.00 \mu \mathrm{M}$, respectively.
\end{abstract}

Keywords: Polygala sibirica; Polygalaceae; flavonol glycosides; inhibition of xanthine oxidase

\section{Introduction}

Polygala sibirica L. var megalopha Fr. (Polygalaceae), a native medicinal plant of Yunnan Province (China), has long been used in folk medicine for the treatment of fever, inflammation, arthralgia and viper bites [1-4]. So far, it was reported that polysaccharides and some novel flavonol and xanthone derivatives had been isolated from this plant [5,6], and some reports on high inhibitory activities against xanthine oxidase by these flavonoids and xanthone derivatives were revealed recently [7-9]. All of this attracted us to further investigate its chemical constituents and seek more compounds as potential xanthine oxidase inhibitors. In the present work, two new compounds, named as polygalin $\mathrm{H}$ (1) and polygalin I (2), and one known compound polygalin D (3) $[10,11]$, were isolated. In this paper, we describe the isolation, structural elucidation of the two new compounds, as well as the inhibition of xanthine oxidase by the three compounds.

\section{Results and Discussion}

Compound 1 was obtained as a yellow amorphous powder. Its molecular formula was determined to be $\mathrm{C}_{30} \mathrm{H}_{36} \mathrm{O}_{17}$ by MALDI-TOF/TOF-MS ( $\mathrm{m} / z$ 691.1077, calcd. for 691.1640, [M+ Na] ${ }^{+}$). The compound exhibited IR absorption bands at 3440 and $1613 \mathrm{~cm}^{-1}$ and UV maximum absorptions $(209,258,273$ and $343 \mathrm{~nm})$, characteristic of a flavonoid. Besides the eleven sugar signals in the ${ }^{13} \mathrm{C}-\mathrm{NMR}$ spectrum, the remaining peaks corresponded to signals of three methoxyl $\left[\delta_{\mathrm{C}} 57.3\right.$ (q), 56.5 (q), 55.6 (q)], one oxygenated methylene $\left(\delta_{C} 60.8, t\right)$, four methines and eleven quaternary carbons. In contrast to polygalin $C$ [11], compound $\mathbf{1}$ has one additional methoxy signal and another oxygenated methylene signal. The oxygenated methylene moiety was deduced to be linked at C-6 
by the HMBC correlations between the oxygenated methylene protons $\mathrm{H}-11\left(\delta_{\mathrm{H}} 4.39, \mathrm{~s}, 2 \mathrm{H}\right)$ and C-6 $\left(\delta_{C} 108.0\right), C-5\left(\delta_{C} 159.3\right), C-7\left(\delta_{C} 163.9\right)$, which was further confirmed by the evidence that the chemical shift of C-6 $\left(\delta_{C} 108.0\right)$ in compound 1 moved 10.2 ppm downfield compared with polygalin C. Simultaneously, in the HMBC spectrum, the long-range correlations between the three methoxyl $\left(\delta_{\mathrm{H}} 3.21,3.91,3.87\right)$ and their corresponding carbons $C-5\left(\delta_{C} 159.3\right), C-7\left(\delta_{C} 163.9\right), C-4^{\prime}\left(\delta_{C} 150.2\right)$, indicated the positions of the methoxy moieties. Therefore, the additional methoxy moiety compared with polygalin $C$ was determined to be linked at C-5. These assignments were further confirmed by the ROSEY spectrum (see Figure 1).

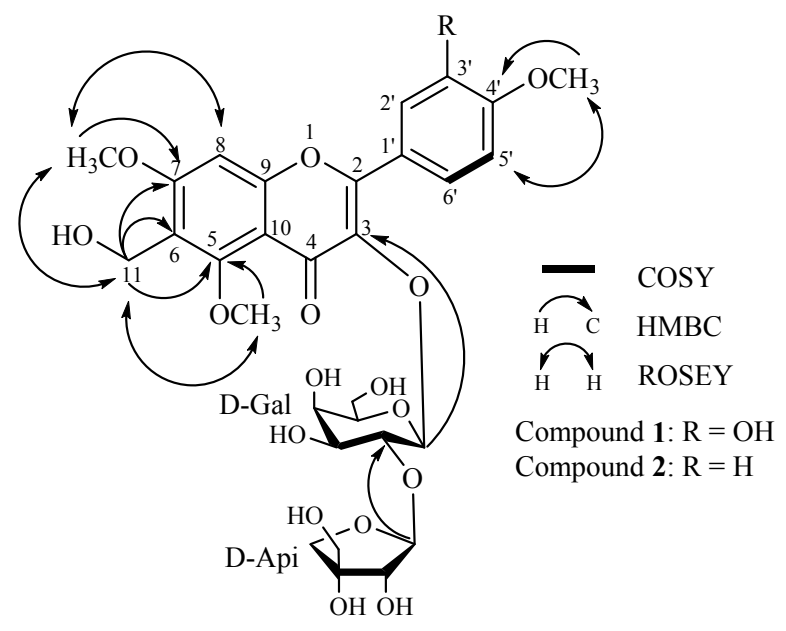

Figure 1. Key COSY, HMBC and ROESY correlations of polygalin H (1) and polygalin I (2).

Acid hydrolysis of 1 with $1 \mathrm{M} \mathrm{HCl}$ afforded two monosaccharides, which were determined to be D-galactopyranose and D-apiofuranose by TLC and GC analysis. In the HMBC spectrum, the long-range correlations indicated that $\mathrm{H}-1^{\prime \prime}\left(\delta_{\mathrm{H}} 5.62, \mathrm{~d}, J=7.7 \mathrm{~Hz}\right)$ of the galactose was attached to $\mathrm{C}-3\left(\delta_{\mathrm{C}} 133.9\right)$ of the aglycone and the $\mathrm{H}-1^{\prime \prime \prime}\left(\delta_{\mathrm{H}} 5.31, \mathrm{~s}\right)$ of the apiose was linked at C-2 ${ }^{\prime \prime}$ $\left(\delta_{C} 74.9\right)$ of the galactose. In addition, the coupling constant $(J=7.7 \mathrm{~Hz})$ of the anomeric proton in galactose revealed its $\beta$-orientation, while the apiose was also deduced to be in an $\beta$-orientation by comparing its ${ }^{13} \mathrm{C}-\mathrm{NMR}$ spectral data $\left(\delta_{C} 108.8,76.1,79.2,73.9,64.2\right)$ with literature data $[12,13]$. Thus, compound 1 was elucidated as 3,3'-dihydroxy-6-hydroxymethyl-5,7,4'-trimethoxyflavone-3-O- $\beta$-Dapiofuranosyl-( $1 \rightarrow 2)-\beta$-D-galactopyranoside (see Figure 1$)$, and was named polygalin $\mathrm{H}$.

Compound 2 was also obtained as a yellow amorphous powder. The MALDI-TOF/TOF-MS provided a molecular formula of $\mathrm{C}_{30} \mathrm{H}_{36} \mathrm{O}_{16}$ at $\mathrm{m} / z$ 675.1942 [M + Na] $]^{+}$(calcd. for 675.1901). The compound showed IR absorption bands at 3441 and $1609 \mathrm{~cm}^{-1}$ and UV maximum absorptions $(209,258,273$ and $343 \mathrm{~nm})$. Comparison of the ${ }^{13} \mathrm{C}-\mathrm{NMR}$ and ${ }^{1} \mathrm{H}-\mathrm{NMR}$ spectral data of compound 2 with those of compound 1, showed that the two compounds had similar structures except for one additional proton signal $\left(\delta_{\mathrm{H}} 7.03, \mathrm{H}-3^{\prime}\right)$ in compound 1. Moreover, the protons of $\mathrm{H}-2^{\prime}$, and $\mathrm{H}-6^{\prime}\left(\delta_{\mathrm{H}} 8.27, \mathrm{~d}, J=8.5 \mathrm{~Hz}\right), \mathrm{H}-3^{\prime}$ and $\mathrm{H}-5^{\prime}\left(\delta_{\mathrm{H}} 7.03, \mathrm{~d}, J=8.5 \mathrm{~Hz}\right)$ in compound 2 exhibited a set of $\mathrm{AA}^{\prime} \mathrm{BB}^{\prime}$-system signals, which indicated that the hydroxyl moiety at $\mathrm{C}-3^{\prime}$ in compound $\mathbf{1}$ was replaced by a hydrogen $\left(\delta_{\mathrm{H}} 7.03, \mathrm{~d}, J=8.5 \mathrm{~Hz}\right)$ in compound 2 . Thus, the compound 2 was elucidated to be 3-hydroxy-6-hydroxymethyl-5,7,4'-trimethoxyflavone-3-O- $\beta$-D-apiofuranosyl- $(1 \rightarrow 2)$ $\beta$-D-galactopyranoside (see Figure 1), and named polygalin I.

It is noteworthy that the hydroxymethyl function in the skeletons of these flavonoids is reported for the first time. Based on the furocoumarin biosynthetic pathway [14], we put forward a hypothesis that polygalin $\mathrm{H}(\mathbf{1})$ is derived from polygalin C, which we also had obtained from P. Sibirica L. Var megalopha Fr. previously. In our hypothesis (see Figure 2), we speculate that compounds $\mathrm{K}$ and $\mathrm{M}$ were unstable, as they were never found among flavones [15-17], and the ultimate product, polygalin $\mathrm{H}$, would be obtained through methylation after L was transformed into N. In our following work, the 
biosynthetic pathway, the chemical properties and bioactivities of flavonoids with this substitution pattern will be further investigated.

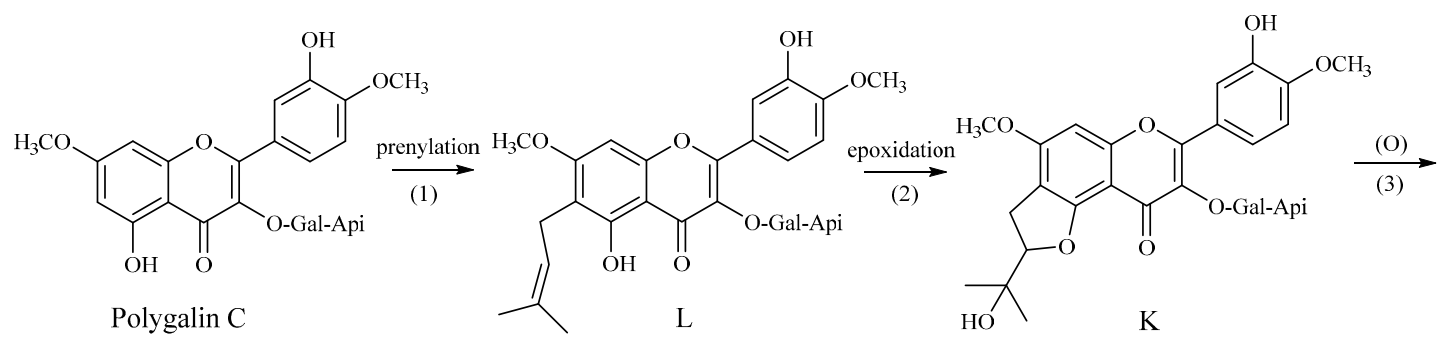

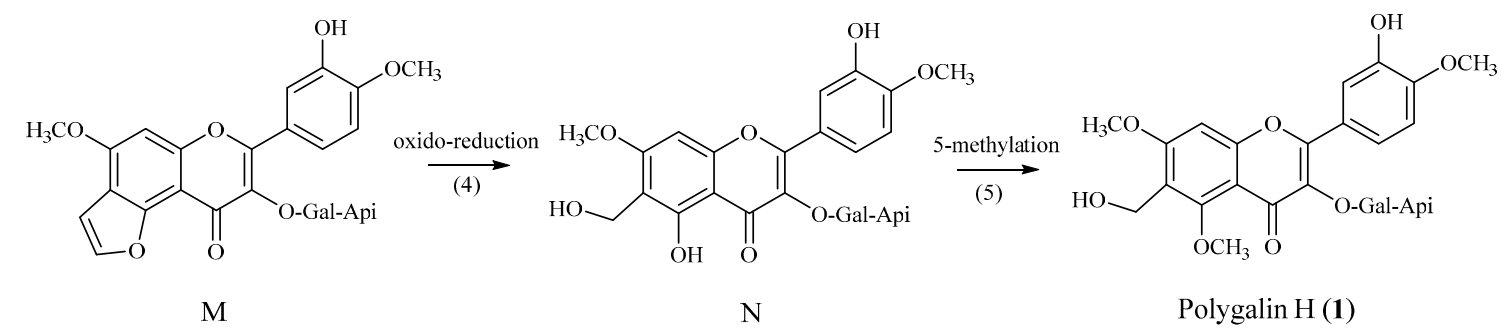

Figure 2. Hypothetical biosynthesis of polygalin $\mathrm{H}(\mathbf{1})$.

Four concentrations $(2.5,5.0,10.0,20.0 \mu \mathrm{M})$ of the flavonol glycosides were analyzed for inhibition of xanthine oxidase, and then the corresponding half-maximal inhibitory concentration $\left(\mathrm{IC}_{50}\right)$ value was calculated (see Table 1 ). The results showed that their $\mathrm{IC}_{50}$ s were 9.48, 8.31, $16.00 \mu \mathrm{M}$, respectively, which were a little higher than the $\mathrm{IC}_{50}$ value $(4.34 \mu \mathrm{M})$ of the positive control, allopurinol. Consequently, this indicated that those three flavonol glycosides had strong inhibitory activities against xanthine oxidase.

Table 1. $\mathrm{IC}_{50}$ values of three flavonol glycosides for inhibition of xantine oxidase.

\begin{tabular}{|c|c|c|c|}
\hline Compound & Final Concentration $(\mu \mathrm{M})$ & Inhibition (\%) & $\mathrm{IC}_{50}(\mu \mathrm{M})$ \\
\hline \multirow{4}{*}{1} & 20.0 & $76.87 \pm 2.0$ & \multirow{4}{*}{9.48} \\
\hline & 10.0 & $43.61 \pm 2.7$ & \\
\hline & 5.0 & $30.71 \pm 0.8$ & \\
\hline & 2.5 & $15.53 \pm 3.8$ & \\
\hline \multirow{4}{*}{2} & 20.0 & $80.87 \pm 4.6$ & \multirow{4}{*}{8.31} \\
\hline & 10.0 & $46.35 \pm 6.6$ & \\
\hline & 5.0 & $33.73 \pm 6.1$ & \\
\hline & 2.5 & $18.45 \pm 5.4$ & \\
\hline \multirow{4}{*}{3} & 20.0 & $58.79 \pm 1.6$ & \multirow{4}{*}{16.00} \\
\hline & 10.0 & $33.81+2.7$ & \\
\hline & 5.0 & $23.74 \pm 1.2$ & \\
\hline & 2.5 & $14.12 \pm 0.6$ & \\
\hline \multirow{4}{*}{ Allopurinol (positive control) } & 20.0 & $96.87 \pm 1.2$ & \multirow{4}{*}{4.34} \\
\hline & 10.0 & $70.61 \pm 4.0$ & \\
\hline & 5.0 & $45.71 \pm 0.8$ & \\
\hline & 2.5 & $37.53 \pm 3.8$ & \\
\hline
\end{tabular}

\section{Experimental Section}

\subsection{General Information}

Optical rotations were recorded using a P-1020 digital polarimeter (Jasco, Tokyo, Japan). The UV spectra were measured on a UV-2401PC spectrophotometer (Shimadzu, Suzhou, China). The IR spectra were recorded as $\mathrm{KBr}$ pellets on a Tensor-27 spectrometer (Bruker, Bremen, Germany). The NMR spectra were recorded on an AM-400 spectrometer (Bruker) with TMS as an internal 
standard. ESI-MS and HR-EI-M-TOF-MS were measured on a Bruker HTC/Esquire spectrometer and a Bruker Daltonics Flex spectrometer, respectively. GC analysis was carried out on an HP-5890 II system (Gentech Scientific, Alto, CA, USA) equipped with a FID detector and a HP-20M capillary column $(25 \mathrm{~m} \times 0.32 \mathrm{~mm} \times 0.3 \mu \mathrm{m})$. Column chromatography was performed with silica gel (Qingdao Marine Chemical Industry Factory, Qingdao, China) and Sephadex LH-20 (GE Healthcare Bio-Sciences AB, Fairfield, CT, USA) and reversed-phase C18 silica gel (40-60 $\mu \mathrm{m}$, Merck, Darmstadt, Germany). TLC was performed with silica gel GF254 (Qingdao Marine Chemical Industry Factory). Fractions were monitored by TLC and spots were visualized by heating after spraying with $5 \% \mathrm{H}_{2} \mathrm{SO}_{4}$ in ethanol.

\subsection{Plant Material}

The whole plant of P. Sibirica L. Var megalopha Fr. were collected in Yongshan, Yunnan Province, People's Republic of China. A voucher specimen (HUA002) was identified by Prof. Fan Du (Southwest Forestry University) and was deposited at the College of Forestry, Southwest Forestry University.

\subsection{Extraction, Isolation and Characterization}

The $75 \%$ ethanol extract of the whole plant of Polygala sibirica L. var megalopha Fr. (5.0 kg), was chromatographed over a $\mathrm{D}_{101}$ macroporous resin, eluted successively with a gradient of $\mathrm{H}_{2} \mathrm{O}, 35 \% \mathrm{EtOH}, 65 \% \mathrm{EtOH}, 95 \% \mathrm{EtOH}$. The $65 \% \mathrm{EtOH}$ eluate was subjected to silica gel column chromatography and eluted with $\mathrm{CHCl}_{3}-\mathrm{MeOH}(50: 1 \rightarrow 0: 1)$ to afford thirteen fractions (Fr.1 $\rightarrow$ Fr.13). Fr.8 (56 g) was chromatographed on a silica gel column and RP-C18 to yield eleven fractions (Fr.8-1 $\rightarrow$ Fr.8-11). Fr.8-7 (35 mg) was purified by Sephadex $\mathrm{LH}-20$ with $\mathrm{CHCl}_{3}-\mathrm{MeOH}$ (1:1) and semi-preparative HPLC with a mixture of acetonitrile and water $(34: 66, v / v)$ to give compound 1 (20 mg). Fr.8-5 (4.654 g) was repeatedly subjected to silica gel column and Sephadex LH-20 chromatography to yield five fractions (Fr.8-5A $\rightarrow$ Fr.8-5E). Fr.8-5C (40.8 mg) was purified by semi-preparative HPLC with a mixture of acetonitrile and water $(29: 71, v / v)$ to afford $2(4.6 \mathrm{mg})$ and 3 (4.3 mg).

Polygalin H (1). Yellow amorphous power; $[\alpha]_{\mathrm{D}}^{20}-89(c 0.0011, \mathrm{MeOH}) ; \mathrm{UV}\left(\mathrm{CH}_{3} \mathrm{OH}\right) \lambda_{\max }(\log \varepsilon)$ : 343 (0.17), 273 (0.19), 258 (0.19), 209 (0.45); IR (KBr) $v_{\max }$ : 3440, 2926, 1613, 1512, 1484, 1354, 1263, $1213,1142,1078,1024 \mathrm{~cm}^{-1}$; for ${ }^{1} \mathrm{H}$ - and ${ }^{13} \mathrm{C}-\mathrm{NMR}$, see Table 2; MALDI-TOF/TOF-MS: $\mathrm{m} / z$ 691.1077 $[\mathrm{M}+\mathrm{Na}]^{+}$(calcd. for 691.1640, $\mathrm{C}_{30} \mathrm{H}_{36} \mathrm{O}_{17} \mathrm{Na}^{+}$).

Polygalin I (2). Yellow amorphous power; $[\alpha]_{\mathrm{D}}^{20}-89(c 0.0011, \mathrm{MeOH}) ; \mathrm{UV}\left(\mathrm{CH}_{3} \mathrm{OH}\right) \lambda_{\max }(\log \varepsilon)$ : 343 (0.17), 273 (0.19), 258 (0.19), 209 (0.45); IR (KBr) $v_{\max }$ : 3441, 2925, 1609, 1510, 1484, 1351, 1258, 1212, 1180, 1077, $1024 \mathrm{~cm}^{-1}$; for ${ }^{1} \mathrm{H}$ - and ${ }^{13} \mathrm{C}-\mathrm{NMR}$, see Table 2; MALDI-TOF/TOF-MS: $\mathrm{m} / \mathrm{z} 675.1942$ $[\mathrm{M}+\mathrm{Na}]^{+}$(calcd. for 675.1901, $\mathrm{C}_{30} \mathrm{H}_{36} \mathrm{O}_{16} \mathrm{Na}^{+}$).

Polygalin D (3). Yellow needles (MeOH); m.p. 251-253 ${ }^{\circ} \mathrm{C} ;[\alpha]_{\mathrm{D}}^{20}-47(c$ 0.51, $\mathrm{MeOH}) ; \mathrm{UV}\left(\mathrm{CH}_{3} \mathrm{OH}\right)$ $\lambda_{\max }(\log \varepsilon) \mathrm{nm}: 268$ (4.12), 355 (3.98); IR (KBr) cm ${ }^{-1}:$ 3410, 2943, 1657, 1601, 1497, 1353, 1218 and 1025. HRESIMS (positive) $m / z: 647.1587$ (calcd. for $\mathrm{C}_{28} \mathrm{H}_{32} \mathrm{O}_{16}, 647.1588$ ]; ${ }^{1} \mathrm{H}-\mathrm{NMR}$ (DMSO- $d_{6}, 600 \mathrm{MHz}$ ) $\delta_{\mathrm{H}}: 7.82\left(1 \mathrm{H}, \mathrm{dd}, J=9.0,2.0 \mathrm{~Hz}, \mathrm{H}-6^{\prime}\right), 7.59\left(1 \mathrm{H}, \mathrm{d}, J=2.0 \mathrm{~Hz}, \mathrm{H}-2^{\prime}\right), 7.03\left(1 \mathrm{H}, \mathrm{d}, J=9.0 \mathrm{~Hz}, \mathrm{H}-5^{\prime}\right)$, $6.72(1 \mathrm{H}, \mathrm{d}, J=2.5 \mathrm{~Hz}, \mathrm{H}-8), 6.38(1 \mathrm{H}, \mathrm{d}, J=2.5 \mathrm{~Hz}, \mathrm{H}-6), 3.88$ (3H, s, 4'-OMe), 3.87 (3H, s, 7-OMe), $5.63(1 \mathrm{H}, \mathrm{d}, J=8.0 \mathrm{~Hz}, \mathrm{Glc}-\mathrm{H}-1) ;{ }^{13} \mathrm{C}-\mathrm{NMR}$ (DMSO-d $\left.{ }_{6}, 150 \mathrm{MHz}\right) \delta: 177.8$ (s, C-4), 165.1 (s, C-7), 161.0 (s,C-5), 156.2 (s, C-9), 155.7 (s, C-2), 150.1 (s, C-4'), 145.0 (s, C-3'), 133.7 (s, C-3), 122.5 (s, C-6'), 121.8 (s, C-1'), 115.5 (s, C-2'), 111.1 (s, C-5'), 108.6 (d, Api-C-1), 105.0 (s, C-10), 98.5 (d, Glc-C-1), 97.8 (s, C-6), 92.1 (s, C-8), 79.2 (s, Api-C-3), 77.5 (d, Glc-C-2), 77.0 (d, Glc-C-3, 5), 76.1 (d, Api-C-2), 73.9 (t, Api-C-4), 70.2 (d, Glc-C-4), 64.2 (t, Api-C-5), 60.8 (t, Glc-C-6), 56.1 (q, 7-OMe), 55.6 (q, 4'-OMe). 
Table 2. The ${ }^{1} \mathrm{H}-\mathrm{NMR}$ and ${ }^{13} \mathrm{C}-\mathrm{NMR}$ data of 1, 2 in DMSO- $d_{6}(600 \mathrm{MHz})$.

\begin{tabular}{|c|c|c|c|c|}
\hline \multirow{2}{*}{ No. } & \multicolumn{2}{|c|}{1} & \multicolumn{2}{|c|}{2} \\
\hline & $\delta_{\mathrm{H}}, J(\mathrm{~Hz})$ & $\delta_{C}$ & $\delta_{\mathrm{H}}, J(\mathrm{~Hz})$ & $\delta_{C}$ \\
\hline 2 & & $155.6 \mathrm{~s}$ & & $155.4 \mathrm{~s}$ \\
\hline 3 & & $133.9 \mathrm{~s}$ & & $133.8 \mathrm{~s}$ \\
\hline 4 & & $177.7 \mathrm{~s}$ & & $177.7 \mathrm{~s}$ \\
\hline 5 & & $159.3 \mathrm{~s}$ & & $159.3 \mathrm{~s}$ \\
\hline 6 & & $108.0 \mathrm{~s}$ & & $108.0 \mathrm{~s}$ \\
\hline 7 & & $163.9 \mathrm{~s}$ & & $163.9 \mathrm{~s}$ \\
\hline 8 & $6.81(\mathrm{~s})$ & $90.3 \mathrm{~d}$ & $6.86(\mathrm{~s})$ & $90.4 \mathrm{~d}$ \\
\hline 9 & & $156.1 \mathrm{~s}$ & & $156.1 \mathrm{~s}$ \\
\hline 10 & & $104.5 \mathrm{~s}$ & & $104.6 \mathrm{~s}$ \\
\hline 11 & 4.39 (s) & $60.8 \mathrm{t}$ & 4.39 (s) & $60.8 \mathrm{t}$ \\
\hline $1^{\prime}$ & & $122.5 \mathrm{~s}$ & & $122.4 \mathrm{~s}$ \\
\hline $2^{\prime}$ & 7.58 (s) & $115.3 \mathrm{~d}$ & $8.27(\mathrm{~d}, 8.5)$ & $130.9 \mathrm{~d}$ \\
\hline $3^{\prime}$ & & $146.1 \mathrm{~s}$ & $7.03(\mathrm{~d}, 8.5)$ & $113.7 \mathrm{~d}$ \\
\hline $4^{\prime}$ & & $150.2 \mathrm{~s}$ & & $161.3 \mathrm{~s}$ \\
\hline $5^{\prime}$ & $6.97(\mathrm{~d}, 8.7)$ & $111.2 \mathrm{~d}$ & $7.03(\mathrm{~d}, 8.5)$ & $113.7 \mathrm{~d}$ \\
\hline $6^{\prime}$ & $7.94(\mathrm{~d}, 8.7)$ & $122.2 \mathrm{~d}$ & $8.27(\mathrm{~d}, 8.5)$ & $130.9 \mathrm{~d}$ \\
\hline 5-OMe & $3.21(\mathrm{~s})$ & $57.3 \mathrm{q}$ & $3.22(\mathrm{~s})$ & $57.3 \mathrm{q}$ \\
\hline 7-OMe & $3.91(\mathrm{~s})$ & $56.5 \mathrm{q}$ & $3.91(\mathrm{~s})$ & $56.5 \mathrm{q}$ \\
\hline $4^{\prime}-\mathrm{OMe}$ & $3.87(\mathrm{~s})$ & $55.6 \mathrm{q}$ & $3.85(\mathrm{~s})$ & $55.4 \mathrm{q}$ \\
\hline Gal-1" & $5.62(\mathrm{~d}, 7.7)$ & $98.9 \mathrm{~d}$ & $5.61(\mathrm{~d}, 7.6)$ & $98.9 \mathrm{~d}$ \\
\hline $2^{\prime \prime}$ & $3.76(\mathrm{~m})$ & $74.9 \mathrm{~d}$ & $3.76(\mathrm{~m})$ & $74.9 \mathrm{~d}$ \\
\hline $3^{\prime \prime}$ & $3.57(\mathrm{~m})$ & $73.8 \mathrm{~d}$ & $3.83(\mathrm{~m})$ & $73.7 \mathrm{~d}$ \\
\hline $4^{\prime \prime}$ & $3.63(\mathrm{~s})$ & $68.3 \mathrm{~d}$ & $3.63(\mathrm{~m})$ & $68.2 \mathrm{~d}$ \\
\hline $5^{\prime \prime}$ & $3.33(\mathrm{~m})$ & $75.8 \mathrm{~d}$ & $3.34(\mathrm{~m})$ & $75.7 \mathrm{~d}$ \\
\hline \multirow[t]{2}{*}{$6^{\prime \prime}$} & $3.42(\mathrm{~m})$ & $60.0 \mathrm{t}$ & $3.41(\mathrm{~m})$ & $60.0 \mathrm{t}$ \\
\hline & $3.27(\mathrm{~m})$ & & $3.25(\mathrm{~m})$ & \\
\hline Api-1"1' & $5.31(\mathrm{~s})$ & $108.8 \mathrm{~d}$ & $5.31(\mathrm{~s})$ & $108.8 \mathrm{~d}$ \\
\hline $2^{\prime \prime \prime}$ & $3.80(\mathrm{~m})$ & $76.1 d$ & $3.81(\mathrm{~m})$ & $76.1 \mathrm{~d}$ \\
\hline $3^{\prime \prime \prime}$ & & $79.2 \mathrm{~s}$ & & $79.2 \mathrm{~s}$ \\
\hline \multirow[t]{2}{*}{$4^{\prime \prime \prime}$} & $3.83(\mathrm{~d}, 9.2)$ & $73.9 \mathrm{t}$ & $3.84(\mathrm{~m})$ & $73.8 \mathrm{t}$ \\
\hline & $3.49(\mathrm{~d}, 9.0)$ & & 3.57 (m) & \\
\hline \multirow[t]{2}{*}{$5^{\prime \prime \prime}$} & $3.42(\mathrm{~m})$ & $64.2 \mathrm{t}$ & $3.41(\mathrm{~m})$ & $64.2 \mathrm{t}$ \\
\hline & $3.37(\mathrm{~m})$ & & $3.34(\mathrm{~m})$ & \\
\hline
\end{tabular}

\subsection{Acid Hydrolysis of Compound 1}

A solution of $1(4.8 \mathrm{mg})$ in $1 \mathrm{M} \mathrm{HCl}(3 \mathrm{~mL})$ was heated in a water bath at $70{ }^{\circ} \mathrm{C}$ for $6 \mathrm{~h}$. After cooling, the reaction mixture was neutralized with $\mathrm{NaHCO}_{3}$ and extracted with $\mathrm{CHCl}$. Through TLC comparison with an authentic sample using EtOAc-EtOH-H2O (5:2:1) as a developing system, galactose and apiose were detected in the water layer $\left(R_{\mathrm{f}}=0.35\right.$ and 0.48 , respectively). The aqueous solution was further concentrated to dryness and dissolved in $1 \mathrm{~mL}$ pyridine. Then hydroxylammonium hydrochloride $(1 \mathrm{mg})$ was added. The solution were kept in a $80^{\circ} \mathrm{C}$ water bath

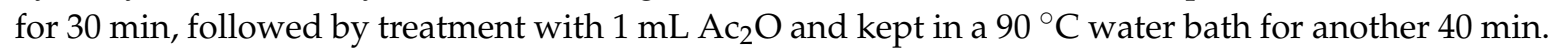
The authentic monosaccharide samples were treated similarly as the hydrolysis products. Finally, $1 \mu \mathrm{L}$ of these acetylated sugars were injected into a HP-20M capillary column using $\mathrm{N}_{2}$ as carrier (oven temp. $210^{\circ} \mathrm{C}$ ) to be analyzed by GC using a FID detector (detector temp. $280^{\circ} \mathrm{C}$ ). Ultimately, the galactose and apiose were confirmed to be both D-configuration by comparing the retention times with those of standard samples: $\mathrm{t}_{\mathrm{R}}$ : D-galactose $12.086 \mathrm{~min}$, D-apiose $4.450 \mathrm{~min}$, respectively.

\subsection{Bioassay of Xanthine Oxidase Inhibitory Activity}

The enzyme xanthine oxidase catalyses the oxidation of xanthine to uric acid. Inhibition of xanthine oxidase results in a decreased production of uric acid. The uric acid production was measured according to the increasing absorbance at $290 \mathrm{~nm}$. Test solutions were prepared by 
adding xanthine (final concentrations $50 \mu \mathrm{M}$ ), hydroxylamine (final concentration $0.2 \mathrm{mM}$ ), EDTA (final concentration $0.1 \mathrm{mM}$ ), and flavonol glycosides in four concentrations $(2.5,5.0,10.0,20.0 \mu \mathrm{M})$. The reaction was started by adding $0.2 \mathrm{~mL}$ of xanthine oxidase $(6.25 \mathrm{mU} / \mathrm{mL})$ in a phosphate buffer solution $\left(\mathrm{pH}=7.50,200 \mathrm{mM}\right.$ ). The mixture (total $1 \mathrm{~mL}$ ) was incubated for $30 \mathrm{~min}$ at $37^{\circ} \mathrm{C}$. Prior to the measurement of uric acid prodution, the reaction was stopped by adding $0.1 \mathrm{~mL}$ of $\mathrm{HCl}$ $(0.58 \mathrm{M})$ [7]. Allopurinol $(2.5,5.0,10.0,20.0 \mu \mathrm{M})$, a known xanthine oxidase inhibitor, was used as a positive control. The $\mathrm{IC}_{50}$ values were calculated by the mean data values from three determinations.

\section{Conclusions}

The chemical investigation of $P$. sibirica L. var megalopha Fr. lead to the isolation of two new polygalin $\mathrm{H}$ (1) and polygalin I (2), as well as one known compound, polygalin D (3). The bioassay in vitro indicated that polygalin $\mathrm{D}$ had a high inhibitory activity against xanthine oxidase with an $\mathrm{IC}_{50}$ of $16.00 \mu \mathrm{M}$. Moreover, those two new flavonol glycosides with rare hydroxymethyl function at C-6 in the skeleton of flavonoids showed stronger inhibitory activities against xanthine oxidase, with an $\mathrm{IC}_{50}$ of $9.48 \mu \mathrm{M}$ for $\mathbf{1}$ and $8.31 \mu \mathrm{M}$ for $\mathbf{2}$, which deserved to be further studied.

Acknowledgments: This work was supported by National Natural Science Foundation of China (No. 31260083) and Scientific Innovation Fund of Southwest Forestry University (No. C1466).

Author Contributions: Y.-J.H., Y.H. and H.-Y.L. designed research; Y.-J.H., L.-Y.Z. and Q.L. performed the isolation and purification of plants, then analyzed the data; Y.-J.H., J.-M.W. and. Y.-Y.G. conducted the bioassay of xanthine oxidase inhibitory activity; Y.-J.H. wrote the paper. All authors read and approved the final manuscript.

Conflicts of Interest: The authors declare no conflict of interest.

\section{References}

1. Chen, S.K.; Li, H.; Chen, B.Y. Flora of China; Science Press: Beijing, China, 1997; p. 195.

2. Wu, Z.Y.; Li, X.W. Yunnan Plant Annals; Science Press: Beijing, China, 1983; p. 287.

3. Luo, X.R. Practical Color Atlas of Chinese Herbal Medicine; Guangdong Science and Technology Press: Guangzhou, China, 1995; pp. 16-17.

4. Yu, H.Z.; Wu, H. Studies on anti-snake venom activity of ethanol extract from Polygala sibirica L. var megalopha Fr. Chin. J. Ethnomed. Ethnopharm. 2008, 17, 3-5.

5. Wei, Y.J.; Zhou, Q.J.; Huang, S.Y.; Zhou, J.; Zhang, J.M.; Wan, Y.; Wu, H. Extraction and purification of Polygala sibirica L. var megalopha Fr. polysaccharrides. J. Jiangsu Norm. Univ. Nat. Sci. Ed. 2014, 31, 60-63.

6. Wan, Y.; Yu, H.Z.; Ye, L.; Zhang, F.R.; Wu, H. Flavonol and xanthone derivatives from Polygala sibirica L. var megalopha Fr. J. Southwest. Univ. 2006, 7, 51-55.

7. Paul, C.; Li, Y.; Mario, C.; Jia, P.H.; Kanyanga, C.; Bart, V.P.; Luc, P.; Arnold, J.V.; Dirk, V.B. Structure-activity relationship and classification of flavonoids as inhibitors of xanthine oxidase and superoxide scavengers. J. Nat. Prod. 1998, 61, 71-76.

8. Zhu, L.L.; Fu, W.W.; Watanabe, S.; Shao, Y.N.; Tan, H.S.; Zhang, H.; Tan, C.H.; Xiu, Y.F.; Norimato, H.; Xu, H.X. Xanthine Oxidase inhibitiors from Garcinia esculenta twigs. Planta Med. 2014, 80, 1721-1726. [PubMed]

9. Li, Y.D.; Frenz, C.M.; Li, Z.W.; Chen, M.H.; Wang, Y.R.; Li, F.J.; Luo, C.; Sun, J.; Borhlin, L.; Li, Z.J.; et al. Virtual and in vitro bioassay screening of phytochemical inhibitors from flavonoids and isoflavones against xanthine oxidase and cyclooxygenase-2 for gout treatment. Chem. Biol. Drug Des. 2013, 81, 537-544. [CrossRef] [PubMed]

10. Song, Y.L.; Zhou, G.S.; Zhou, S.X.; Jiang, Y.; Tu, P.F. Polygalins D-G, four new flavonol glycosides from the aerial parts of Polygala sibirica L. (Polygalaceae). Nat. Prod. Res. 2013, 27, 1220-1227. [CrossRef] [PubMed]

11. Li, T.Z.; Zhang, W.D.; Yang, G.J.; Liu, W.Y.; Liu, R.H.; Zhang, C.; Chen, H.S. New flavonol glycosides and new xanthone from Polygala japonica. J. Asian Nat. Prod. Res. 2006, 8, 401-409. [CrossRef] [PubMed]

12. Endo, K.; Takahashi, K.; Abe, T.; Hikino, H. Structure of forsythoside B, an antibacterial principle of Forsythia koreana stems. Heterocycles 1982, 19, 261-264.

13. Nicoletti, M.; Galeffi, C.; Multari, G.; Garbarino, J.A.; Gambaro, V. Polar constituents of Calceolaria ascendens. Planta Med. 1988, 54, 347-348. [CrossRef] [PubMed] 
14. Yao, X.S.; Wu, L.J.; Wang, Z.P.; Kong, L.Y.; Wu, J.Z.; Yi, Y.H.; Zhao, Y.Y.; Hu, C.Q. Natural Pharmaceutical Chemistry; People's Medical Publishing House: Beijing, China, 2001; pp. 110-112.

15. Veitch, N.C.; Grayer, R.J. Flavonoids and their glycosides, including anthocyanins. Nat. Prod. Rep. 2008, 25, 555-611. [CrossRef] [PubMed]

16. Harborne, J.B.; Williams, C.A. Anthocyanins and other flavonoids. Nat. Prod. Rep. 2001, 18, $310-333$. [CrossRef] [PubMed]

17. Harborne, J.B.; Williams, C.A. Anthocyanins and other flavonoids. Nat. Prod. Rep. 1998, 15, 631-651. [CrossRef]

Sample Availability: Sample of compound $\mathbf{1}$ (approximately $2 \mathrm{mg}$ ) are available from the authors. Samples of compound $\mathbf{2}$ and $\mathbf{3}$ are not available.

(C) 2015 by the authors; licensee MDPI, Basel, Switzerland. This article is an open access article distributed under the terms and conditions of the Creative Commons by Attribution (CC-BY) license (http://creativecommons.org/licenses/by/4.0/). 